\title{
Perhitungan Skala Biaya Kerugian akibat Tumpahan Minyak: Relevansinya untuk Perairan Indonesia
}

\author{
Mauludiyah $^{1)}$ dan Mukhtasor ${ }^{2)}$ \\ ${ }^{1)}$ Mahasiswa Pasca Sarjana Teknik Manajemen Pantai ITS \\ ${ }^{2)}$ Dosen Pasca Sarjana Teknologi Kelautan ITS, Anggota Dewan Energi Nasional (DEN) dari \\ Unsur Stakeholder Lingkungan Hidup
}

\begin{abstract}
ABSTRAK
This paper argues that it is a need to approach oil spills problems by incorporating economic losses associated with the spills. Indonesia's position is very strategic for commercial sea traffics and for a number of oil and gas industries, making it important to consider marine pollution from oil spills. This pollution can reduce water quality and result in environmental impacts and economic losses. This paper presents figure that a total cost due to oil spills can be estimated with a function of spill size alone based on data considering environmental degradation, socio-economic losses and clean-up costs. The calculation was undertaken by using the approach estimates the total cost of losses as a function of the volume of oil spills because the volume are the main factor governing the level of contamination and its impact, the type of clean-up and the total spill cost. A scale of the cost of economic losses caused by oil spills in Indonesian waters is estimated. The estimates show that the cost of economic losses due to oil spills in the Indonesian area is in the range of 183 billion to 9.757 billion rupiahs. The calculation in this paper is still a low-level estimation and not site-specific yet, because the assessment instruments used are based on conditions in the North German area. It is expected by this preliminary effort, impact assessment and economic losses due to oil spills in Indonesian waters will be equipped with further studies on an analysis of economic losses supported with more comprehensive and specific data.
\end{abstract}

Key words: clean-up cost; environmental damage; economic effect and losses; marine pollution; oil spills.

\section{Pendahuluan}

Posisi geografis Indonesia sangat strategis bagi lalu lintas perdagangan melalui laut. Wilayah perairan seperti Selat Malaka menjadi jalur yang banyak diminati kapal-kapal tanker asing yang mengangkut minyak mentah dan produk-produknya. Selain itu, industri eksplorasi dan produksi perminyakan Indonesia juga banyak berada di laut dan umumnya berdekatan dengan pantai seperti yang terdapat di Selat Malaka, Laut Jawa dan sebelah timur Kalimantan [1]. Hal ini berarti potensi pencemaran akibat tumpahan minyak di perairan Indonesia harus selalu diwaspadai.

Minyak merupakan senyawa kimia yang kompleks, lebih dari separuh bagiannya terdiri dari hidrokarbon dan turunannya. Ketika minyak tumpah di laut, interaksinya dengan air laut menghasilkan berbagai jenis proses yang dapat mengubah komposisi dan karakteristik minyak di lingkungan laut, seperti adveksi, difusi, dispersi, sedimentasi, emulsi, penguapan, pelarutan, degradasi mikroba dan fotokimia $[1,2]$.

Peristiwa tumpahan minyak (oil spill) di lingkungan laut dapat menurunkan kualitas air laut, baik karena efek langsung (short term effect) maupun yang lebih membahayakan, yaitu efek dalam jangka panjang (long term effect). Secara fisik, pencemaran minyak akan tampak sangat jelas karena permukaan laut tertutup lapisan minyak atau gumpalan ter (ter balls). Secara kimia, karena minyak bumi tergolong senyawa aromatik hidrokarbon maka dapat bersifat racun yang dapat mematikan organisme laut. Sedangkan secara biologi, adanya buangan atau tumpahan minyak dapat mempengaruhi kehidupan organisme laut maupun manusia secara tidak langsung.

Ofiara [3] menyatakan bahwa efek biologi dari pencemaran laut yang terjadi akan menghasilkan dampak dan kerugian ekonomi. Irisan dari dua area tersebut seringkali tidak dimasukkan dalam studi dampak pencemaran lingkungan laut, padahal pencemaran laut dapat menghasilkan dampak dan kerugian ekonomi yang besar apabila tidak ditangani dan dikelola dengan baik. Sebuah studi menunjukkan bahwa 10 tahun setelah terjadi tumpahan minyak Exxon Valdez, daerah perikanan di dekat pantai dalam area tumpahan minyak masih terekspose residu hidrokarbon sehingga, dari hasil analisis yang dilakukan, maka kerugian ekonomi yang ditimbulkan sangat besar [4,5]. 
Makalah ini menyajikan suatu upaya untuk mengukur total kerugian secara ekonomi yang disebabkan oleh tumpahan minyak dari beberapa kasus tumpahan minyak yang terjadi di Indonesia. Hal ini dilakukan mengingat kasus tumpahan minyak telah banyak terjadi di perairan Indonesia (Tabel 1) dan besarnya dampak kerusakan yang ditimbulkannya, baik secara ekologi maupun ekonomi. Total kerugian ekonomi didapatkan melalui pendekatan dengan model yang mengestimasi biaya yang diakibatkan kerusakan lingkungan, baik secara langsung maupun tidak langsung, dan respon terhadap tumpahan minyak, sebagai fungsi dari volume tumpahan minyak. Sejumlah studi mengenai valuasi ekonomi tumpahan minyak telah dilakukan [5-12], namun secara spesifik, untuk kasus tumpahan minyak di perairan Indonesia belum pernah dilakukan.

Tabel 1. Peristiwa Tumpahan Minyak di Perairan Indonesia

\begin{tabular}{|c|c|c|}
\hline Tahun & Lokasi & Kejadian \\
\hline 1975 & Selat Malaka & $\begin{array}{l}\text { Kandasnya Tanker Showa Maru dan menumpahkan } 1 \text { juta ton minyak } \\
\text { mentah }\end{array}$ \\
\hline 1975 & Selat Malaka & Tabrakan kapal tanker Isugawa Maru dengan kapal Silver Palace \\
\hline 1979 & Buleleng, Bali & Tanker Choya Maru karam dan menumpahkan 300 ton bensin \\
\hline 1979 & Lhokseumawe, NAD & $\begin{array}{l}\text { Tanker Golden Win bocor dan menumpahkan } 1.500 \text { kiloliter minyak tanah } \\
\text { Semburan liar pengeboran minyak milik Total Indonesia }\end{array}$ \\
\hline 1984 & Delta Mahakam, Kaltim & Tabrakan kapal MT. Ocean Blessing dengan MT. Nagasaki Spirit yang \\
\hline 1992 & Selat Malaka & menumpahkan 5000 barel minyak mentah \\
\hline 1993 & Selat Malaka & Karamnya Tanker Maersk Navigator yang memuat minyak mentah \\
\hline 1994 & Cilacap & Tabrakan antara Tanker MV. Bandar Ayu dengan kapal ikan \\
\hline 1996 & Natuna & Tenggelamnya KM. Batamas II yang memuat MFO \\
\hline 1997 & Kepulauan Riau & $\begin{array}{l}\text { Tabrakan antara Tanker Orapin Global dengan Evoikos menumpahkan } \\
25000 \text { ton minyak mentah }\end{array}$ \\
\hline 1997 & Kepulauan Riau & Kebocoran pipa transfer minyak CALTEX \\
\hline 1997 & Selat Makasar & Tenggelamnya tanker Mission Viking \\
\hline 1997 & Selat Makasar & Kandasnya platform E-20 UNOCAL \\
\hline 1997 & Selat Madura & Tenggelamnya Tanker SETDCO \\
\hline 1998 & Tanjung Priok & Kandasnya kapal Pertamina Supply No. 27 dengan muatan solar \\
\hline 1999 & Cilacap & $\begin{array}{l}\text { Robeknya Tanker MT. King Fisher dengan menumpahkan } 640000 \text { liter } \\
\text { minyak dan mencemari Teluk Cilacap sepanjang } 38 \text { km }\end{array}$ \\
\hline 2000 & Cilacap & Tenggelamnya KM. HHC yang memuat 9000 aspal curah \\
\hline 2000 & Batam & Kandasnya MT. Natuna Sea menumpahkan 4000 ton minyak mentah \\
\hline 2001 & Tegal-Cirebon & Tenggelamnya Tanker Steadfast yang mengangkut 1200 ton minyak \\
\hline 2002 & Perairan Singapura & $\begin{array}{l}\text { Tabrakan Tanker Singapura Agate dan Kapal Petikemas Tian Yu, } \\
\text { mencemari pulau Bintan dan } 4 \text { kecamatan di Pulau Batam }\end{array}$ \\
\hline 2003 & Sungai Musi & $\begin{array}{l}\text { Tabrakan kapal Beras milik PT Toba Pulp Lesatari Angiang Shipping } \\
\text { dengan Tongkang PLTU } 1 \text { mengakibatkan tumpahnya } 250 \text { ton minyak } \\
\text { bahan bakar diesel milik PLTU Keramasan }\end{array}$ \\
\hline 2004 & Riau & $\begin{array}{l}\text { Tenggelamnya Tanker Vista Marine yang menumpahkan } 200 \text { ton minyak } \\
\text { mentah }\end{array}$ \\
\hline 2008 & Indramayu & $\begin{array}{l}\text { Tanker Arendal mengalami kebocoran pipa dan menumpahkan } 150 \text { ribu } \\
\text { DWT minyak }\end{array}$ \\
\hline 2008 & Selat Malaka & $\begin{array}{l}\text { Tanker Aegis Leader kandas dan menumpahkan } 550 \text { ton minyak mentah } \\
\text { Terbaliknya tanker MT. Kharisma Selatan yang menumpahkan } 500\end{array}$ \\
\hline 2009 & Pelabuhan Tanjung Perak & kiloliter MFO (marine fuel oil) \\
\hline & Surabaya & Ladang minyak Montara meledak dan menumpahkan sekitar 500 ribu liter \\
\hline 2009 & Laut Timor & minyak mentah ke laut setiap hari \\
\hline
\end{tabular}

\section{Pendekatan Perhitungan Biaya Kerugian akibat Tumpahan Minyak}

Secara umum, metodologi untuk menentukan biaya akibat tumpahan minyak dilistrasikan pada Gambar 1. Biaya yang timbul akibat tumpahan minyak dapat diestimasi dari 3 (tiga) komponen, yaitu biaya kerusakan lingkungan dan sosial-ekonomi serta biaya clean-up tumpahan minyak. Dalam perhitungan biaya tumpahan minyak yang terjadi di perairan Indonesia dengan metode tersebut menemukan beberapa kesulitan diantaranya adalah tidak tersedianya data pengukuran dampak tumpahan minyak pada lingkungan laut dan data yang mengindikasikan aktivitas ekonomi sebelum dan sesudah kejadian tumpahan minyak. 


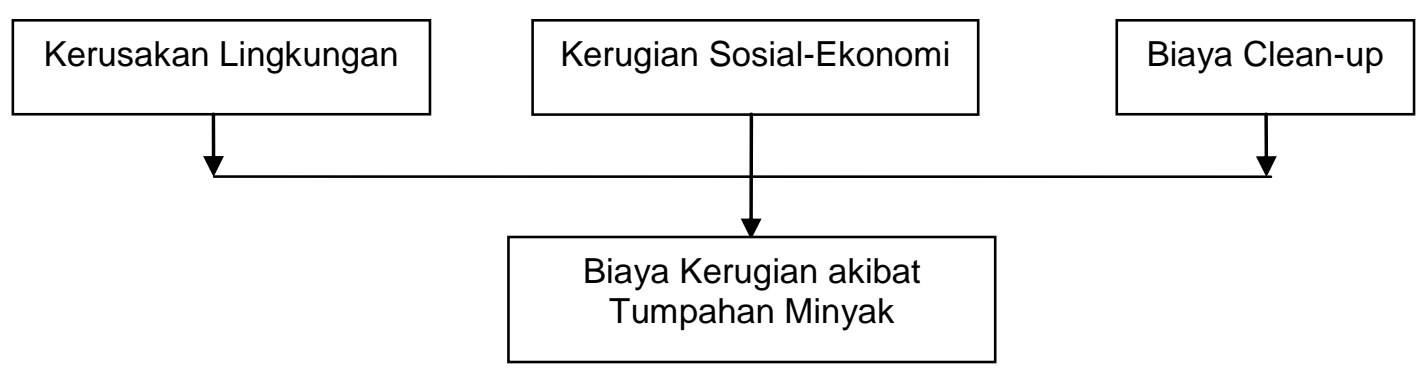

Gambar 1. Komponen biaya pada perhitungan kerugian yang diakibatkan oleh tumpahan minyak

\subsection{Kerusakan Lingkungan}

Laut yang tercemar oleh tumpahan minyak akan membawa pengaruh negatif bagi berbagai organisme laut. Pencemaran air laut oleh minyak juga berdampak terhadap beberapa jenis burung. Air yang bercampur minyak juga akan mengganggu ekosistem spesifik yang ada di perairan pesisir dan laut, seperti terumbu karang, hutan mangrove dan juga rusaknya wisata pantai. Tumpahan minyak juga akan menghambat/mengurangi transmisi cahaya matahari ke dalam air laut karena diserap oleh minyak dan dipantulkan kembali ke udara.

Respon lingkungan terhadap tumpahan minyak sangat kompleks, dapat tergantung pada jumlah minyak yang tumpah, tipe eksposure, tipe minyak, lokasi dan waktu kejadian minyak tumpah, densitas tumpahan minyak dan kepekaan (sensitivitas) ekosistem terhadap minyak [1, 13]. Secara umum, sensitivitas terhadap minyak meningkat dari invertebrata tingkat rendah ke tingkat invertebrata yang lebih tinggi, dan kemudian ke ikan. Hal ini disebabkan ikan mempunyai kemampuan untuk berenang dan menghindari area yang terkontaminasi minyak. Tahap larva umumnya paling sensitif terhadap minyak dibandingkan dengan yang lainnya.

Dampak dari tumpahan minyak dapat berupa penurunan pertumbuhan, penurunan produksi, perubahan sistem metabolisme dan biomagnifikasi hidrokarbon. Telah banyak dilaporkan bahwa keragaman dan densitas populasi komunitas bentik mengalami penurunan signifikan pada area yang terkontaminasi minyak. Komunitas bentik dan nekton adalah organisme kunci, baik secara ekologis maupun ekonomis, pada ekosistem laut. Komunitas bentik bersifat sensitif terhadap eksposure petroleum hidrokarbon [13]. Komunitas bentik merupakan jalur penting pada transfer kontaminan dari sedimen pada level tropik yang lebih tinggi.

Selain tumpahan minyak itu sendiri, masalah lain yang juga kompleks adalah pembersihan tumpahan minyak (clean-up) karena dapat menyebabkan kerusakan yang signifikan pada komunitas lahan basah termasuk penurunan tingkat pertumbuhan tanaman dan penurunan populasi organisme bentik [13]. Sejumlah studi mengenai dampak tumpahan minyak terhadap organisme laut, ekosistem dan lingkungan laut telah dilakukan $[4,7,13-17]$.

Tumpahan minyak akan memberikan dampak yang signifikan pada lingkungan laut. Kerugian secara biologi dapat diestimasi dari kematian organisme dewasa dan hilangnya produktivitas (short term) dan kematian larva dan juvenil serta hilangnya pertumbuhan akibat kematian organisme dewasa (long term) [14]. Efek jangka panjang mungkin terjadi selama beberapa tahun sebelum pemulihan ekosistem. Tumpahan bahkan bisa membawa perubahan permanen dalam ekosistem sebagaimana dibuktikan dengan munculnya spesies baru atau perbedaan flora dan fauna sebelum dan sesudah terjadi tumpahan minyak.

Kerusakan lingkungan akibat tumpahan minyak ini dapat diestimasi dengan menggunakan persamaan sebagai berikut [10]:

$$
L=\sum_{t=0}^{b}(1-f(t))\left(\frac{1}{1+d}\right)^{t}
$$

Area dimana kerusakan lingkungan terjadi, $L$, dapat diestimasi dengan menggunakan fungsi timedependent recovery $f(t)$, untuk mendeskripsikan potensi habitat atau populasi yang terkena 
dampak, sehingga lingkungan yang rusak selama tahun ke- $t$ setelah kejadian tumpahan minyak adalah $1-f(t)$. Area yang terkena dampak merupakan penjumlahan hingga tahun ke $b$ dimana kerusakan lingkungan telah dapat pulih kembali. $d$ adalah discount rate tahunan yang nilainya direkomendasikan NOAA dalam [10] adalah sebesar 0,03.

Nilai kerugian dari habitat atau populasi yang terkena dampak, $V$, kemudian dihitung dengan:

$$
V=M \cdot Q \cdot L
$$

$Q$ merupakan jumlah total unit sumber daya yang terkena dampak dan $M$ adalah nilai ekonomi per unit sumber daya, sehingga nilai total kerugian $T$ dapat dihitung dengan penjumlahan seluruh individu yang terkena dampak pada setiap sumber daya sepeti ditunjukkan pada persamaan (3) berikut.

$$
T \sum_{i=1}^{n} V_{i}=\sum_{i=1}^{n} M_{i} \cdot Q_{i} \cdot L_{i}
$$

\subsection{Kerugian Sosial-Ekonomi}

Komponen minyak yang bertahan di permukaan atau yang telah terlarut di badan air merupakan bahan beracun (toxic) yang membahayakan kelestarian lingkungan laut dan mengganggu fungsi peruntukan laut lokasi terjadinya tumpahan. Kondisi kehidupan beranekaragam organisme di laut dapat terganggu, terutama organisme sensitif yang terekspose minyak. Tumpahan minyak juga menyebabkan kerusakan fisik lingkungan laut dan menurunkan nilai keindahannya. Secara keseluruhan, tumpahan minyak menyebabkan kerugian ekonomi, baik secara langsung (misalnya kerusakan fisik dan biologis) maupun secara tidak langsung (misalnya turunnya potensi pariwisata).

Valuasi ekonomi dampak lingkungan merupakan proses kuantifikasi dan pemberian nilai (valuasi) ekonomi terhadap dampak lingkungan setelah terlebih dahulu dilakukan identifikasi. Valuasi ekonomi diperlukan dalam upaya menunjukkan bahwa aspek lingkungan bukan sebagai halangan bagi pembangunan tetapi merupakan potensi penting untuk jangka panjang. Dengan demikian upaya untuk mendekati nilai lingkungan tersebut perlu dilakukan untuk mengingatkan para pengambil keputusan akan pentingnya dampak yang timbul dari sebuah kegiatan terhadap Ingkungan hidup (Pearce, 1987 dalam Kay dan Alder [19]).

Garza-Gil et. al. [12] menyatakan bahwa penilaian biaya sosial dari tumpahan minyak dihubungkan dengan penilaian kerusakan yang komprehensif untuk tujuan kompensasi. Hal ini dapat dilakukan dengan pendekatan biaya privat dan biaya publik/kolektif. Biaya privat biasanya dibatasi pada beberapa kelompok atau individu yang terkena dampak pencemaran (ada aktivitas ekonomi dimana nilai pasar tersedia), misalnya pada sektor perikanan dan turisme. Sedangkan biaya publik/kolektif sering diidentifikasi dengan analisa pasar/marketed: clean up atau restorasi; dan analisa non pasar/non marketed: rekreasi (active use) dan biodiversitas (passive use).

Range kerusakan akibat tumpahan minyak, baik langsung atau tidak langsung, sangatlah lebar, seperti pengaruhnya pada daerah perairan yang produktif, perikanan atau rekreasi, sehingga lingkungan laut mengalami perubahan yang signifikan. Penilaian terhadap kerusakan yang dihasilkan tumpahan minyak tersebut selanjutnya digunakan untuk mengestimasi dampak secara ekonomi. Dampak ekonomi juga dapat diestimasi dari kerugian ekonomi secara global yang dihubungkan dengan kegiatan perikanan, turisme, aktivitas pelabuhan dan rekreasi [7]. Pada sektor perikanan, estimasi dampak ekonomi tumpahan minyak dapat diprediksi dari faktor-faktor seperti hubungan antara spesies dengan substratum, sensitivitas spesies terhadap minyak, cara memangsa (prey) dan usaha perikanan itu sendiri [6].

Sebuah analisis biaya-dampak membutuhkan perbandingan perubahan kesejahteraan dari semua pihak yang terkena dampak pencemaran. Karena itu diperlukan informasi tingkat kesejahteraan sebelum dan sesudah pencemaran terjadi. Ini membutuhkan model yang dapat memprediksi besarnya dampak yang akan ditimbulkan oleh pencemaran yang terjadi pada setiap pihak dalam masyarakat. Dalam tahap ini dihitung kerugian yang diderita oleh semua pihak akibat pencemaran 
yang terjadi. Terutama, memperkirakan dampak kerusakan terhadap lingkungan dan kehidupan ekonomi masyarakat yang tergantung pada lokasi perairan di sekitar terjadinya tumpahan minyak.

Liu \& Wirtz [10\} menyatakan bahwa kerugian ekonomi (economic losses, EL) adalah penjumlahan dari pendapatan yang hilang selama masa pemulihan yang diberikan pada persamaan (4).

$$
E L=\sum_{i=1}^{n} y r_{i} \cdot \sum_{t=0}^{p_{i}}(1-f(t)) \cdot\left(\frac{1}{1+d}\right)^{t}
$$

dimana $y r_{i}$ adalah pendapatan tahunan untuk sektor ekonomi $i, f(t)$ merepresentasikan persentase relatif dari sektor yang terkena dampak i pada tahun $t$ kejadian, $d$ merupakan discount rate tahunan dan $p_{i}$ adalah waktu (dalam tahun) yang diperlukan untuk pemulihan kembali.

\subsection{Biaya Clean-up Tumpahan Minyak}

Biaya clean-up tumpahan minyak dipengaruhi oleh beberapa faktor, dimana hal yang terpenting adalah lokasi kejadian dan tumpahan minyak serta volume tumpahan minyak. Biaya clean-up, selanjutnya disebut juga dengan biaya respon tumpahan minyak (Response Cost, $R C$ ), melingkupi pembersihan minyak dari perairan laut, membawa peralatan menuju lokasi tumpahan dan mobilisasi tim penanggulangan (clean-up) tumpahan minyak. $R C$ dapat diestimasi dengan menjumlahkan semua biaya fasilitas pembersihan minyak, termasuk vessel dan pekerja. Hal ini dapat dihitung dengan mengalikan unit harga fasilitas pembersihan dan durasinya seperti pada persamaan berikut [10]:

$$
R C=\sum_{j=1}^{n} u p_{j} \cdot d u_{j}
$$

dimana $u p_{j}$ adalah unit harga vessel $j$, sedangkan $d u_{j}$ merepresentasikan durasi dari penggunaan fasilitas vessel $j$.

Selain estimasi di atas, Shahriari \& Frost [8] dalam studinya membuat model untuk memprediksi biaya clean-up tumpahan minyak di lingkungan laut.

$$
\begin{aligned}
& R C=-1.1124 \times 10^{8}+572.0984\left(\mathrm{x}_{1}\right)+1.2227 \times 10^{8}\left(\mathrm{x}_{2}\right)+1.7050 \times 10^{5}\left(\mathrm{x}_{3}\right)-3.5948 \times 10^{4}\left(\mathrm{x}_{4}\right)+4.3803 \times 10^{6}\left(\mathrm{x}_{5}\right) \\
& R C=-2.4261 \times 10^{8}+707.6067\left(\mathrm{x}_{1}\right)+2.5658 \times 10^{8}\left(\mathrm{x}_{2}\right)+1.0409 \times 10^{7}\left(\mathrm{x}_{5}\right) \\
& R C=-5.0785 \times 10^{4}+6.5230 \times 10^{4}\left(\mathrm{x}_{2}\right)-59.5582\left(\mathrm{x}_{3}\right)-86.1654\left(\mathrm{x}_{4}\right)+2.1519 \times 10^{3}\left(\mathrm{x}_{5}\right) \\
& R C=-4.6547 \times 10^{4}+5.5490 \times 10^{4}\left(\mathrm{x}_{2}\right)+1.6251 \times 10^{3}\left(\mathrm{x}_{5}\right)
\end{aligned}
$$

Persamaan (6) merupakan model full cost, persamaan (7) merupakan model reduced cost, persamaan (8) merupakan model full per ton dan persamaan (9) merupakan model reduced per ton. Nilai $x_{1}$ adalah jumlah minyak tumpah dalam ton, $x_{2}$ adalah densitas minyak tumpah dalam $\mathrm{kg} / \mathrm{dm}^{3}, \mathrm{x}_{3}$ adalah jarak tumpahan minyak dari pantai, $\mathrm{x}_{4}$ adalah persentase cloudineas (\%) dan $\mathrm{x}_{5}$ adalah level of preparedness.

Gambar 2 mengilustrasikan hubungan antara jumlah besaran tumpahan minyak (dalam ton) dengan biaya clean-up di perairan Norwegia. Sedangkan Gambar 3 mengilustrasikan rata-rata biaya clean-up pada tiap kawasan yang berbeda. 


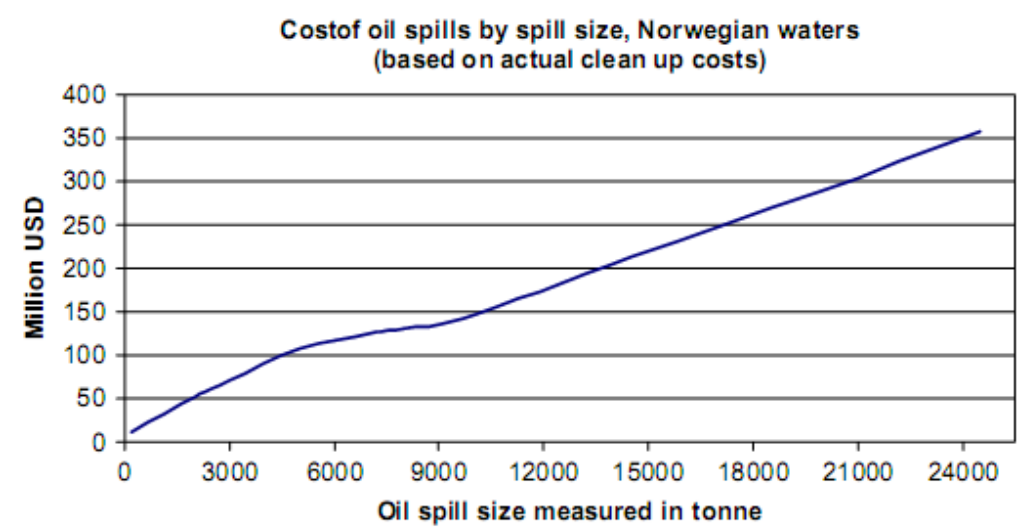

Gambar 2. Biaya clean-up di perairan Norwegia (Hansen, J., 2003 dalam [9])

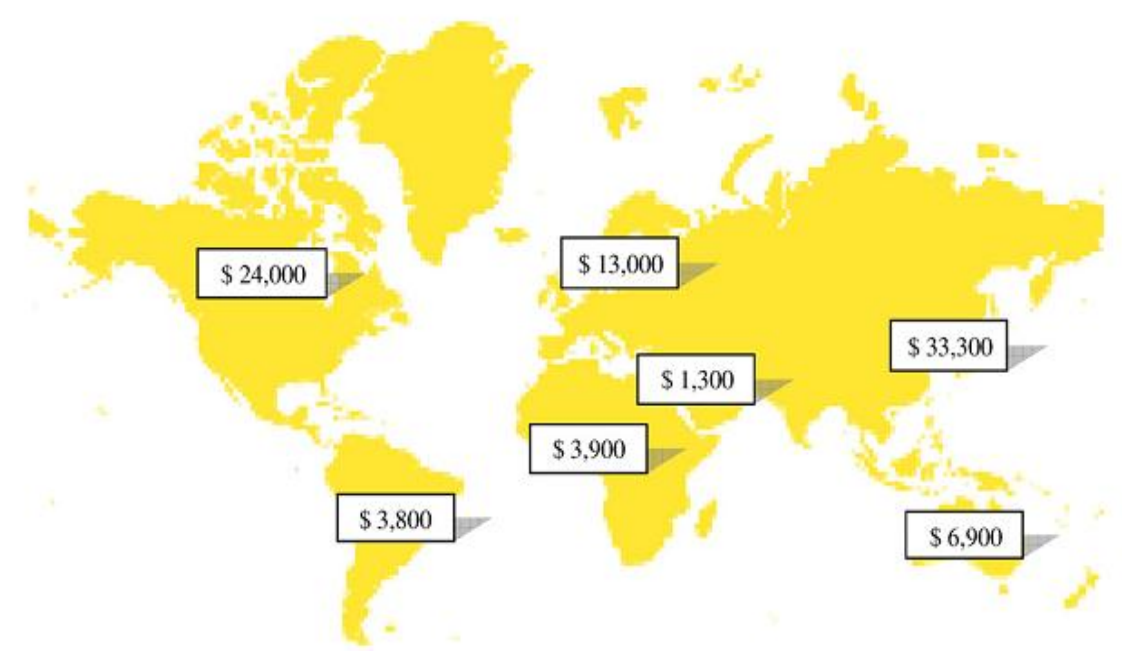

Gambar 3. Rata-rata biaya clean-up per ton (US\$2006) di beberapa kawasan (Etkin, D.S., 2000 dalam [9])

\section{Perkiraan Kerugian Ekonomi Tumpahan Minyak di Perairan Indonesia}

Vegetasi bawah air ekosistem (seperti terumbu karang, padang lamun dan rumput laut) sangat sensitif terhadap kontaminasi minyak, memiliki produktivitas yang tinggi, berperan dalam siklus nutrien, berfungsi sebagai kawasan asuhan, mencari makan dan berlindung berbagai spesies penting dan ikan-ikan yang mempunyai nilai komersial tinggi. Sehingga apabila daerah ini terekspose tumpahan minyak maka dampaknya akan besar karena nilai ekonomisnya yang tinggi, mengingat Indonesia adalah negara terkaya di dunia dalam hal keragaman hayati (biodiversitas). Vegetasi pada daerah pasang surut (seperti ekosistem mangrove) akan lebih rentan karena langsung terkontaminasi oleh lapisan minyak di permukaan perairan. Begitu juga dengan kawasan yang produktif seperti kawasan yang diperuntukkan sebagai area perikanan budidaya maupun perikanan tangkap, pariwisata, maupun yang diperuntukkan sebagai jasa transportasi, kegiatan industri di wilayah pesisir dan pemukiman masyarakat.

Biaya dari tumpahan minyak juga akan dipengaruhi oleh faktor alami seperti tipe minyak. Tipe minyak akan mempengaruhi bagaimana perilaku dan dampak kerusakan yang ditimbulkan ketika masuk ke lingkungan laut. Light refined products seperti gasoline, kerosene (minyak tanah) dan beberapa light crude oil adalah material yang mempunyai volatilitas tinggi dan viskositas yang rendah sehingga akan cepat mengalami penguapan dan dispersi, sehingga pada kasus tumpahan dengan tipe minyak tersebut tidak diperlukan clean-up. Hal ini juga berarti tipe minyak akan mempengaruhi jenis clean-up yang akan digunakan. 
Lokasi kejadian tumpahan minyak juga menjadi hal penting dalam perhitungan biaya tumpahan minyak. Karakter fisik pada lokasi kejadian tumpahan minyak, seperti angin, pasang surut, arus, gelombang dan kedalaman laut, akan berpengaruh pada perilaku minyak. Selanjutnya dari perilaku minyak tersebut akan mempengaruhi dampak yang ditimbulkan dan jenis clean-up yang akan digunakan. Faktor sosial ekonomi dan resiko sumber daya yang terkena dampak tumpahan pun bervariasi pada setiap lokasi. Variasi ini tidak hanya berpengaruh pada tingkat dampak yang diterima tetapi juga akan membantu menentukan jenis clean-up yang akan digunakan.

Selain faktor-faktor di atas, volume tumpahan juga menjadi hal yang sangat penting untuk menentukan besarnya kontaminasi dan kerusakan yang terjadi, jenis clean-up yang digunakan dan tentunya biaya total kerusakan [11]. Seperti tragedi Exxon Valdez di Prince William Sound, Alaska, Amerika Serikat (1989), yang menumpahkan 10,8 juta galon (sekitar 41 juta liter) minyak mentah. Selain menimbulkan dampak lingkungan yang signifikan, juga secara ekonomi mengakibatkan biaya pemulihan yang sangat fantastis. Dibutuhkan dana sekitar 6,2 milyar Dolar AS (sekitar Rp9,5 triliun kurs saat itu), termasuk ganti rugi sebesar 1,1 miliar Dolar AS (Rp1,6 triliun) harus dikeluarkan oleh perusahaan untuk membersihkan minyak mentah yang tumpah saat tanker raksasa tersebut karam di perairan Teluk Alaska [20].

Liu \& Writz [10] mendekati permasalahan ini, dengan memodelkan estimasi biaya tumpahan minyak yang dihubungkan dengan karakteristik utama yang mempengaruhinya, yaitu volume tumpahan minyak. Hal ini dilakukan untuk mendefinisikan range dampak yang potensial terjadi, sebelum studi lebih lanjut dilakukan. Secara ringkas metode perhitungan biaya yang diakibatkan oleh tumpahan minyak ditunjukkan pada Gambar 1.

Setiap tahapan perhitungan pada makalah ini mempunyai ketidakpastian karena keterbatasan data yang tersedia maupun keterbatasan metodologi dari model yang digunakan. Selanjutnya, metode penilaian ekonomi dari tumpahan minyak pada makalah ini dilakukan dengan mengestimasi biaya total tumpahan minyak, baik langsung dan tidak langsung, sebagai fungsi dari volume tumpahan minyak yang masuk ke perairan/lingkungan laut yang diberikan pada persamaan (10) Liu dan Wirtz [10].

$$
\operatorname{Ln}(T C)=0,4667 \text { \&n }(t)+13,894
$$

dimana TC merupakan total biaya dalam juta Euro dan $t$ merupakan besaran tumpahan minyak dalam ton yang masuk ke lingkungan laut.

Persamaan ini didapatkan dari menyimulasikan 72 skenario tumpahan minyak yang terjadi di perairan Jerman Utara. Perhitungan total biaya tiap skenarionya merupakan penjumlahan dari tiga kategori biaya yang mempengaruhi biaya tumpahan minyak yang telah diuraikan sebelumnya, yaitu kerusakan lingkungan, kerugian sosial ekonomi dan biaya clean-up.

Prediksi biaya pembersihan tumpahan minyak dalam skala lokal terkadang dapat dimodelkan dengan akurat dengan menggunakan satu variabel seperti disajikan pada Gambar 2. Pada gambar tersebut terlihat bahwa hubungan antara volume tumpahan minyak dengan biaya clean-up mendekati linier.

Dari hasil perhitungan didapatkan estimasi biaya total kerugian akibat tumpahan minyak di perairan Indonesia (Tabel 2). Hasil ini belum mencerminkan biaya total dari seluruh peristiwa tumpahan minyak yang pernah terjadi di Indonesia. Hal ini dikarenakan tidak tersedianya data volume minyak tumpah pada setiap kasus peristiwa tumpahan minyak yang pernah terjadi. Dari Tabel 2 terlihat bahwa biaya yang dikeluarkan atau kerugian secara ekonomi akibat tumpahan minyak sangatlah besar, yaitu terletak dalam range 183 miliar hingga 9.757 miliar rupiah.

Tabel 2. Perkiraan Biaya/Kerugian Total dari Sejumlah Tumpahan Minyak di Perairan Indonesia

\begin{tabular}{clccc}
\hline Tahun & \multicolumn{1}{c}{ Peristiwa Tumpahan Minyak } & Volume (Ton) & $\begin{array}{c}\text { Biaya Total Kerugian } \\
\text { (juta Euro) }\end{array}$ & $\begin{array}{c}\text { Biaya Total Kerugian } \\
(\text { miliar Rp)** }\end{array}$ \\
\hline \hline 1975 & Tanker Showa Maru - Selat Malaka & 1.000 .000 & 683 & 9.757 \\
1979 & Tanker Choya Maru - Buleleng, Bali & 300 & 15 & 221 \\
1979 & Tanker Golden Win - Lhokseumawe NAD & 1.230 & 30 & 428 \\
1992 & MT Ocean Blessing vs MT Nagasaki Spirit & 722 & 23 & 334
\end{tabular}




\begin{tabular}{|c|c|c|c|c|}
\hline & Selat Malaka & & & \\
\hline 1997 & Tanker Orapin Global vs Evoikos - Riau & 25.000 & 122 & 1.744 \\
\hline 1999 & MT. King Fisher - Cilacap & 589 & 21 & 303 \\
\hline 2000 & MT Natuna Sea - Batam & 4.000 & 52 & 742 \\
\hline 2001 & Tanker Steadfast - Tegal Cirebon & 12.000 & 87 & 1.238 \\
\hline 2003 & $\begin{array}{l}\text { Kapal PT Toba Pulp vs Tonkang PLTU } 1 \\
\text { Sungai Musi }\end{array}$ & 250 & 14 & 203 \\
\hline 2004 & Tanker Vista Marine - Riau & 200 & 13 & 183 \\
\hline 2008 & Tanker Arendal- Indramayu & 150.000 & 282 & 4.025 \\
\hline 2008 & Tanker Aegis Leader - Selat Malaka & 550 & 21 & 294 \\
\hline 2009 & $\begin{array}{l}\text { MT Kharisma Selatan - } \\
\text { Pel. Tanjung Perak, Surabaya }\end{array}$ & 430 & 18 & 262 \\
\hline 2009 & Montara - Laut Timor* & 27.600 & 128 & 1.827 \\
\hline
\end{tabular}

Pada kasus spesifik di Pantai Sepinggan, Balikpapan (2004), biaya pembersihan pantai akibat pencemaran tumpahan minyak sebesar Rp. 167.350.000,00. Sedangkan pengolahan sludge dari penimbunan sementara adalah Rp. 1.550.500.000,00. Untuk perbaikan mangrove, perikanan, biaya asesmen dan biaya lingkungan berturut-turut adalah $R p$. 60.900.000,00; Rp. 4.101.000.000,00; Rp. 3.697.161.581,00 dan Rp. 4.494.630.313,00. Sehingga total biaya akibat tumpahan minyak adalah sebesar Rp. 14.071.541.894,00. Dasar perhitungan di atas merupakan hasil workshop valuasi ekonomi kerugian pencemaran minyak di Kota Balikpapan yang diselenggarakan pada tanggal 19 Agustus 2004 (Tim Advokasi Tumpahan Minyak (TATUM) Balikpapan, Sekretariat Badan Pengelola Teluk Balikpapan, Mitra Pesisir (CRMP II) Kalimantan Timur di Balikpapan dan Institut Hukum Sumberdaya Alam (IHSA) Kaltim) [20]. Tampak bahwa biaya penanggulangan (clean-up) adalah sekitar $12 \%$ dari total biaya akibat tumpahan minyak di Pantai Sepinggan, Balikpapan.

Pada Gambar 3 diilustrasikan bahwa biaya clean-up tumpahan minyak bervariasi pada tiap kawasan. Biaya rata-rata clean-up bervariasi antara 1.000 US $\$$ per ton hingga 33.000 US $\$$ di tiaptiap kawasan tersebut. Dengan menggunakan asumsi estimasi biaya clean-up di kawasan Australia (dikarenakan letaknya yang lebih dekat dengan Indonesia secara geografis) sebesar 6.900 US\$ per ton dan perhitungan kasus spesifik di pantai Sepinggan, Balikpapan, maka perhitungan biaya total akibat tumpahan minyak di perairan Indonesia yang dilakukan pada makalah ini masih terletak di dalam range tersebut, kecuali pada beberapa kasus dengan volume tumpahan minyak yang sangat besar.

Perhitungan biaya kerugian tidak bisa berlaku sama untuk semua keadaan peristiwa tumpahan minyak melainkan bersifat site-spesific. Faktor sosial-ekonomi dan penilaian sumber daya alam/lingkungan berbeda-beda pada setiap lokasi terjadinya tumpahan minyak. Demikian juga dengan kondisi lingkungan perairan dimana pencemaran akibat tumpahan minyak terjadi. Perhitungan yang dilakukan pada makalah ini masih merupakan perkiraan secara kasar karena instrumen penilaian yang digunakan adalah berdasarkan kondisi di perairan Jerman Utara. Sehingga untuk mengkaji kasus spesifik yang terjadi dibutuhkan data, informasi, estimasi dan asumsi yang spesifik dan komprehensif agar perhitungan lebih bersifat site-spesific. Meskipun demikian, metode perhitungan biaya total kerugian akibat tumpahan minyak dengan pendekatan ini dilakukan untuk memberikan gambaran mengenai tingkat kerugian ekonomi yang disebabkan pencemaran lingkungan laut akibat tumpahan minyak, sebelum studi lebih lanjut dilakukan. Hal ini dikarenakan sesungguhnya masalah biaya atau ekonomi, baik jangka pendek maupun jangka panjang, adalah penting bagi pemerintah, masyarakat dan juga lingkungan.

Dalam situasi dimana deteksi tumpahan minyak masih belum banyak dilakukan dan proses cleanup yang masih cenderung lamban serta tidak didukung dengan penegakan hukum yang kuat, maka investasi dalam pencegahan dan proses penanggulangan terjadinya tumpahan minyak (clean-up) akan cenderung rendah, padahal kerugian ekonomi yang ditimbulkan adalah besar [18]. Sehingga kemudian dari informasi ini diharapkan dapat dibentuk sistem yang tepat dalam pengelolaan resiko akibat tumpahan minyak sekaligus rancangan instrumen peraturan sehingga 
dampak pencemaran dapat diminimalisir. Kemudian lebih lanjut dapat disusun sejumlah kebijakan yang relevan dan efektif untuk pencegahan maupun clean-up pencemaran laut akibat tumpahan minyak, termasuk kebutuhan untuk pengembangan suatu infrastruktur ekonomi alternatif untuk menggantikan kerugian akibat tumpahan minyak yang terjadi.

\section{Kesimpulan dan Saran}

Posisi Indonesia yang sangat strategis bagi lalu lintas perdagangan melalui laut dan juga banyaknya industri minyak dan gas yang berada di laut menyebabkan potensi terjadinya pencemaran tumpahan minyak. Peristiwa ini dapat menurunkan kualitas air laut, baik karena efek langsung (short term effect) maupun efek dalam jangka panjang (long term effect). Peritiwa ini juga akan menghasilkan dampak dan kerugian secara ekonomi.

Makalah ini memberikan gambaran bahwa dalam pencemaran lingkungan laut akibat tumpahan minyak, ekonomi dapat menyediakan penilaian yang komprehensif, serta menawarkan kerangka kerja untuk merancang sistem, instrumen peraturan dan kebijakan sehingga dampak pencemaran dapat diminimalisir.

Dalam makalah ini dipaparkan biaya yang dapat timbul akibat pencemaran laut oleh tumpahan minyak dapat berasal dari kerusakan lingkungan, kerugian sosial-ekonomi dan biaya clean-up. Selanjutnya, disajikan skala biaya kerugian ekonomi yang disebabkan oleh tumpahan minyak yang terjadi di perairan Indonesia. Perhitungan dilakukan dengan menggunakan pendekatan estimasi biaya total kerugian sebagai fungsi volume tumpahan minyak [9] karena volume tumpahan minyak merupakan karakteristik utama yang menentukan tingkat kontaminasi dan dampak yang ditimbulkan, jenis clean-up yang digunakan serta biaya total yang ditimbulkan. Hasil perhitungan menunjukkan bahwa biaya kerugian ekonomi akibat tumpahan minyak di perairan Indonesia berada dalam range 183 miliar hingga 9.757 miliar rupiah.

Perhitungan yang dilakukan pada makalah ini masih merupakan perkiraan secara kasar karena instrumen penilaian yang digunakan adalah berdasarkan kondisi di perairan Jerman Utara. Meskipun perkiraan biaya tersebut masih merupakan perkiraan tingkat rendah, namun jika dilihat dari besarnya total biaya yang dihasilkan, maka sesungguhnya biaya atau ekonomi, baik jangka pendek maupun jangka panjang, adalah hal yang penting bagi pemerintah, masyarakat dan juga lingkungan. Diharapkan dengan upaya pendahuluan ini, penilaian dampak dan kerugian ekonomi pencemaran lingkungan laut akibat tumpahan minyak di perairan Indonesia akan dilengkapi dengan studi lebih lanjut mengenai analisis kerugian ekonomi yang lebih komprehensif dengan didukung data-data spesifik yang relevan. Suatu model nilai kerugian representatif yang memudahkan pengambil keputusan juga merupakan kebutuhan yang penting.

\section{Daftar Pustaka}

[1] Mukhtasor, Pencemaran Pesisir dan Laut, Pradnya Paramita, 2007.

[2] Burns, Kathryn A., Viewpoint: Analytical Methods Used in Oil Spill Studies, Marine Pollution Bulletin, 26 (2), 68-72, 1993.

[3] Ofiara, D. D. \& Seneca J. J., Review: Biological Effects and Subsequent Economic Effects and Losses from Marine Pollution and Degradations in Marine Environments: Implications from The Literature, Marine Polluton Bulletin 52, 844-864, 2006.

[4] Jewett, S. C., Dean, T. A., Woodin, B. R., Hoberg, M. K., Stegeman, J. J., Exposure to Hydrocarbons 10 Years After The Exxon Valdez Oil Spill: Evidence from Cytochrome P4501A Expression and Biliary FACs in Nearshore Demersal Fishes, Marine Environmental Research 54, 21-48, 2002.

[5] Loureiro, M. L., Ribas, A., López, E., Ojea, E., Estimated costs and admissible claims linked to the PrestigePrestige oil spill, Ecological Economics 59, 48 - 63, 2006.

[6] Negro Garcia, M. C., Villasante, S., Penela, A. C., Rodriguez, G. R, Estimating The Economc Impact of The Prestige Oil Spill on The Death Coast (NW Spain) Fisheries, Marine Policy 33, 8-23, 2009.

[7] Castanedo, S., Juanes, J.A., Medina, R., Puente, A., Fernandez, F., Olabarrieta, M., Pombo, C., Oil spill vulnerability assessment integrating physical, biological and socio-economical aspects: Application to the Cantabrian coast (Bay of Biscay, Spain), Journal of Environmental Management 91, 149-159, 2009. 
[8] Shahriari, M. \& Frost, A., Oil Spill Cleanup Cost Estimation: Developing A Mathematical Model for Marine Environment, Process Safety and Environment Protection 86, 189-197, 2008.

[9] Vanem, E., Endresen, O., Skjong, R., Cost-effectiveness Criteria for Marine Oil Spill Preventive Measures, Reliability Engineering and System Safety 93, 1354-1368, 2008.

[10] Liu, X. \& Wirtz, K. W., The Economy of Oil Spills: Direct and Indirect Costs as A Function of Spill Size, Journal of Hazardous Materials 171, 471-477, 2009.

[11] White, I. C. \& Nichols, J. A., The Cost of Oil Spills, Marine Pollution Bulletin, 12 (11), 363367, 1981.

[12] Garza-Gil, M. D., Suris-Regueiro, J. C., Varela-Lafuente, M. M., Assessment of Economic Damages from The Prestige Oil Spill, Marine Policy 30, 544-551, 2006.

[13] Ko, Jae-Young \& Day, John W., A Review of Ecological Impacts of Oil and Gas Development on Coastal Ecosystems in The Mississippi Delta, Ocean \& Coastal Management, 47, 597-623, 2004.

[14] Reed, M., French, D., Grigalunas, T., Opaluch, J., Overview of Natural Resource Damage Assessment Model System for Coastal and Marine Enviroments, Oil \& Chemical Pollution 5, 85-97, 1989.

[15] Boehm, P. D., Neff, J. M., Page, D. S., Baseline: Assessment of Polycyclic Aromatic Hydrocarbon Exposure in The Waters of Prince William Sound After The Exxon Valdez Oil Spill: 1989-2005, Marine Pollution Bulletin 54, 339-367, 2007.

[16] Alvarez, C. A., Perez, C., Velando, A., Effects of Acute Exposure to Heavy Fuel Oil from The Prestige Spill on A Seabird, Aquatic Toxycology 84, 103-110, 2007.

[17] McCay, D. F., Rowe, J. J., Whittier, N., Sankaranarayanan, S., Etkin, D. S., Estimation of Potential Impacts and Natural Resource Damages of Oil, Journal of Hazardous Materials 107, 11-25, 2004.

[18] Okogu, B. E., Oil spill hazards at the upstream Level: A risk management paradigm for a developing country, Energy Policy, 22 (5), 393-402, 1994.

[19] Kay, R. \& Alder, J., Coastal Planning and Management, E\&FN Spon, London, 1999.

[20] http://www.ihsa.or.id/kasus.php?id=75\&awal=\&akhir=\&PHPSESSID=788ae8a8bb31cfe2818 9ff61692406a9 